\title{
Using reading to teach English as a foreign language
}

\section{El uso de la lectura para la enseñanza del Inglés como lengua extranjera}

\author{
Marcelo Bernal $^{1}$ (D), Paúl Bernal ${ }^{2}$ \\ ${ }^{1}$ Psychology School, Language Department, Universidad de Cuenca, Av. 12 de abril, Cuenca. \\ ${ }^{2}$ Language Department, Universidad de Cuenca, Av. 12 de abril, Cuenca. \\ Corresponding author: marcelo.bernal@ucuenca.edu.ec \\ Reception date: November 3, 2020 - Acceptance date: November 15, 2020
}

\begin{abstract}
Generally, teaching English as a foreign language (EFL) at elementary, secondary, and university levels in Ecuador focuses primarily on applying teacher-centered approaches or on merely following up on the English textbooks' scope and sequence. There is much emphasis on developing grammar skills, practicing isolated concepts, and studying different realities depicted in commercial textbooks while neglecting students' real interests and needs. These traditional practices have created conscious and unconscious conditioning in students, and a significant number of instructors think that English learning is contingent upon grammar rules and the repetition of irrelevant and unnecessary notions, which results in low student academic performance. This descriptive study proposes the use of reading as an educational tool for improving the English teaching and learning process. The researchers applied five reading comprehension tests, three related to General English and two to Academic English, and a confidence level in reading comprehension questionnaire to 37 A1/A2 English third-level university students. Measures of central tendency and variability were used for data analysis. Results show significant improvements in understanding and analyzing texts, high confidence levels for reading in English, and better overall language learning. We suggest making replicas of these didactical practices in other courses offered at the university level.
\end{abstract}

Keywords: EFL learning, didactics, reading, confidence, teaching approaches.

\section{RESUMEN}

Generalmente, la enseñanza del Inglés como lengua extranjera (ILE) en los niveles primario, secundario y universitario en Ecuador se enfoca principalmente en aplicar metodologías centradas en el profesor o simplemente en seguir contenidos y las secuencias de los libros de texto en inglés. Por regla general, se pone mucho énfasis en el desarrollo de habilidades gramaticales, la práctica de conceptos aislados y el estudio de las diferentes realidades descritas en los libros de texto comerciales, descuidando los intereses y necesidades reales de los estudiantes. Estas prácticas tradicionales han creado un condicionamiento consciente e inconsciente en los estudiantes, y un número significativo de profesores piensan que el aprendizaje del inglés depende de las reglas gramaticales y la repetición de nociones irrelevantes e innecesarias, lo que resulta en un bajo rendimiento académico de los estudiantes. Este estudio descriptivo propone el uso de la lectura como herramienta educativa para la mejora del proceso de enseñanza y aprendizaje del inglés. Se aplicaron cinco pruebas de comprensión lectora, tres relacionadas con el inglés general y dos con el inglés académico y un cuestionario de nivel de confianza en comprensión lectora a 37 estudiantes universitarios de tercer nivel de inglés, niveles A1/A2. Se utilizaron medidas de tendencia central y variabilidad para el análisis de datos. Los resultados muestran mejoras significativas en la comprensión y el análisis de textos, altos niveles de confianza para leer en inglés y un mejor aprendizaje general del idioma. Se sugiere realizar réplicas de estas prácticas didácticas en otros cursos que se ofrecen a nivel universitario.

Palabras clave: ILE, aprendizaje, didáctica, lectura, confianza, metodología de enseñanza.

\section{INTRODUCTION}

English teaching professionals worldwide wonder about what are the best teaching practices that should be used to teach English, and in general, how to introduce reading and writing to their daily work. Traditionally, teachers of English as a second language (ESL) or as a foreign language (EFL) have taken the reading and writing separately from each other (Tsai, 2006). Most of them have concentrated on using English teaching methodologies that mainly emphasize the repetition of grammar structures, vocabulary, isolated, and artificial language contents. As an overall result, those types of approaches have caused discouragement, boredom, frustration, and even aversion regarding learning English in elementary, high school, and university students. Universidad de Cuenca (UC) students, in most cases, take English courses only to comply with a compulsory requirement for graduation, which generally leads them to 
dislike the English language. However, Ecuador is in urgent need of emphasizing English learning to be part of a globalized world. The director of the National Ministry of Education, Science, Technology, and Innovation stated that if Ecuadorians do not know English, they will be lost in this era of knowledge because almost $90 \%$ of publications are in English (Ramírez, 2013). According to the Consejo de Educación Superior (2016), for students to complete undergraduate study programs, they must acquire at least a B1 level of the Common European Framework level of proficiency for Languages (CEFRL) (Trim, Coste, North, \& Sheils, 2001).

Likewise, it is widely known that English language knowledge and acceptable proficiency is a must in master as well as doctoral graduate programs, where there is an essential component of scientific and academic reading. Therefore, it is imperative to rethink the methodologies and tools currently used for teaching and learning English as a foreign language. As the core contribution of this study, the authors believe that the use of reading to teach EFL might be the answer to achieving the necessary English language knowledge and proficiency. Thus, students will comply with the national and international educational requirements for foreign languages for Ecuadorian university undergraduate as well as graduate students.

Based on the aforementioned perspectives, the research questions addressed in this study are the following:

- Does the level of reading comprehension increase both in General and Academic English when using reading as a foundation to teach EFL?

- Is there a significant difference in the scores between Academic versus General English?

- Is there a significant gain in the English language macro skills during this English course?

- What are the students' levels of confidence when reading General and Academic English?

\section{REVIEW OF LITERATURE}

Many EFL and ESL researchers have agreed that reading is an essential academic skill to develop as a tool to learn ESL or EFL. Yan (2017) in her article about close reading, states that reading is one of the most important ways for human beings to process information and that reading, and literacy education, is always a critical part of different levels of education (p.38). In university settings, reading is considered as a primary means of acquiring new information and gaining access to alternative explanations and interpretations. However, English learners must go beyond these simple practices and engage in the reading text by having a purpose for reading. Paul \& Elder (2008) point out that learners should read for pure pleasure, to gain specific technical information, to figure out a simple idea, or to enter, understand, and appreciate a new world view (p.1). Grabe \& Stoller (2001) mention that many $\mathrm{EFL/ESL}$ researchers have argued that reading is the most critical academic language skill for second language learners. It also offers the possibility of learning synthesis and critical evaluation skills and independent learning whether the objective is to perform better academically, learn more about the subject matter or improve overall language skills (p.1).

The ability to read can be the most crucial skill to develop when learning a foreign language and of paramount importance to teach in ESL/EFL courses. O’Malley \& Chamot (1990) on their reading strategy framework of Metacognitive and Cognitive skills emphasize the need for teaching ESL/EFL students strategies such as previewing the main ideas, self-monitoring, selfevaluation, skimming, scanning, guessing, recognizing cognates and word families, reading for meaning, deducing, predicting, activating general knowledge, making inferences, following references, separating main ideas from supporting ones, note-taking, summarizing and so on (p.144). Additionally, reading selected by instructors (Intensive Reading) and reading for pleasure (Extensive Reading) are part of reading programs of several English curricula offered in different ESL/EFL courses.

On the one hand, intensive reading can be used in academic settings where technical English can be part of an EFL course, as indicated by Torrie (2017). She points out that EFL students need to read and write about topics related to their majors in technology, math, and science (p.22). Bernal \& Feyen (2017), on an EFL postsecondary university setting study, 106 psychology students acknowledged that when introducing reading as the main component of the English program at the Psychology School, it allowed them to improve their listening, writing, comprehension, and speaking skills. On the other hand, Toland \& Fuisting (2017) indicated that extensive reading or reading for pleasure can also be successfully implemented in a diverse array of English language learning contexts included ESL and EFL. There are also studies such as Day (2015) that analyzed how L2 students improved their reading rates through the practice of extensive readings when allowing students to choose their materials.

Another study carried out in an EFL Japanese context done by Taguchi, Takayasu-Maass, \& Gorsuch (2004) focused on whether and how assisted repeated reading (ARR) following an auditory reading model enhances EFL readers' fluency. The results of this study show that repetition and listening components of ARR play an essential role to facilitate reading comprehension and potentially develop weak ESL/EFL readers' fluency and help them become independent readers.

Beglar, Hunt, \& Kite (2012) investigated the effects of one year of reading for pleasure on the reading rate development of 97 Japanese first-year students. The results showed that the three reading for pleasure groups improved 8.02, 12.84, and 16.85 standard wpm $^{1}$, respectively, while the intensive reading group improved only 2.97 standard wpm (pp.20-22).

Narrow Reading (NR) is another type of reading approach that we can utilize in EFL settings. According to Krashen (1996), McQuillan (2016), and Schmitt \& Carter (2000), NR is a type of reading introduced in ESL/EFL courses in which readers focus on the work of a single author or a single topic throughout several texts for an extended period. Chang \& Millet (2017) carried out a study in an EFL setting where they used narrow reading. They compared the reading speed, comprehension, and perceptions of two groups of EFL students. Each group

${ }^{1} \mathrm{Wpm}$ : words per minute 
focused on one of two types of narrow reading: the same genre and the same title. EFL students responded positively to narrow reading, especially to the same title treatment.

Chang (2012) investigated the effect of timed reading (TR) and repeated oral reading (ROR) in two groups of 35 EFL adult students. Results showed the rate gains of both groups were retained after six weeks with no additional instruction, the increasing of reading amount improved, and that the ROR did not affect reading comprehension.

Top-down and Bottom-up Reading Strategies and Reading Comprehension have also been used in ESL/EFL contexts. A study carried out by Chen \& Yang (2015) states that lexical recognition and syntactic knowledge are indispensable for EFL readers to better their reading comprehension and that integrating reading strategies instruction into language courses potentially impact EFL learners' reading comprehension.

In the bottom-up approach, students are taught to focus on vocabulary and the structure of passage during reading. Even though bottom-up techniques have been considered as the most appropriate learning methodology by authors, such as Aebersold \& Field (1997) and Khaki (2014), they sustain that top-down methodology is more effective since students use their prior knowledge to have a close interaction with a written text.

A study conducted by Bernal \& Feyen (2017) in an Ecuadorian university points out that students had the opportunity to work with psychology texts as a way of learning English as a Foreign Language. They had the freedom to choose readings they were interested in, which allowed them to acquire high levels of overall comprehension. However, authors such as Kintsch (2005), Eskey \& Grabe (1988), and Grabe \& Stoller (2001) suggest the use of a combined approach where the reader decides which approach is more beneficial. In other words, by lack of previous knowledge of what students are reading, a bottom-up approach would be more appropriate. Nevertheless, if readers possess background knowledge of what they are reading, a top-down methodology would be more helpful.

The interactive feature of reading needs to be highlighted to help students involve themselves actively while reading, which in turn will encourage them to use different strategies. The use of strategies to develop reading skills is determinant. In this regard, extensive and intensive reading plays a decisive role in planning appropriate teaching approaches. On the one hand, extensive reading, defined as reading large amounts of texts focusing on general understanding without performing any tasks after reading (Loh, 2009), is considered useful when developing language proficiency. Conversely, Richard \& Smith (2002) recommend the administration of intensive reading programs in a regular language course to develop reading habits, encourage knowledge of grammar structures and vocabulary, and nurture the love of reading.

Furthermore, Brophy (1986) indicates that providing students with challenging tasks offers students the opportunity to learn "thoughtful information-processing and skill-building strategies" with reasonable amounts of effort. Moreover, practicing these reading approaches, in turn, increases students' responsibility for their learning. Miller (2003) states that challenging tasks offer students the opportunity to use prior knowledge and construct an understanding of a topic, which engages students in a teaching and learning activity.

Considering reading in a foreign language as a complex process, which involves two crucial acquisition areas: understanding information and enhancing language proficiency, the design of specific tasks as suggested by Mounts \& Smirnova (2011) might be essential for facilitating comprehension. The paragraph-by-paragraph reading technique, recommended by these two authors, views a paragraph as a complete text with its own semantic and structural organization. Therefore, tasks may aim at obtaining and understanding information, as well as evaluating and reflecting on it.

According to Tsai (2006), the use of reading for writing and writing for reading are two strategies for reading instruction that facilitate learning a foreign language in the EFL/ESL classroom. Additionally, Pluck (2013) points out that the introduction of reading academic and scientific articles to English teaching in postsecondary contexts presents additional challenges for students, but the overall benefits are also significant.

Krashen (2004) points out that both children and adults who practice recreational reading show better development in reading, writing, grammar, and vocabulary. Similarly, Krashen (1985) indicated that the best way to improve reading is by reading and that English instructors should guide students to choose their reading material at a level of comprehension that allows "comprehensible input". He also advocated that the use of reading in regular English courses enables students to develop a basic understanding of written texts. It, in turn, enables them to acquire the necessary language constructs such as grammar, rules for writing, listening, speaking, and so on, thereby facilitating language acquisition.

Meyer (2014), in her Evaluation report of an Ecuadorian university, believes that including the reading of academic and general English materials gives the possibility of having learning outcomes of a B2 level of the Common European Framework Reference for Languages (CEFRL).

Feyen (2014), in his PowerPoint presentation on "How to bring research into teaching", in postsecondary education settings indicates that it is necessary to develop the four language skills: listening, speaking, reading, and writing. To increase reading, he recommends further motivating students to read articles related to the course content. For writing exercises, he advises asking students to prepare outlines or short summaries of the reading material. For speaking activities, students need to practice oral presentations in the classroom on what they have read, and for listening practice, students must listen to comments and suggestions from their instructor and peers.

The University of Cuenca in Ecuador, in recent years, has been in a transition process from being a teaching university to a teaching university with research and internationalization perspectives. Therefore, the authors argue that it is vital to include more reading activities in research, teaching, and administrative practices. A reading university is a university with a clear vision and mission which will progress and become more known and competitive. Outside observers of the English teaching situation at the Universidad de Cuenca (UC) such as Meyer (2014) and Feyen (2014) claim that it is necessary to rethink the implementation of different teaching practices where the emphasis must be on reading as the primary tool for the acquisition of a foreign language. This 
new approach will boost students', instructors', and researchers' English reading practices.

Pablo Vanegas, the President of the Universidad de Cuenca (UC), in Meyer's report (2014), confirms the need to include reading exercises in the English curricula since it is one of the essential skills to develop. Reading can be taken as the foundation for the development of the remaining language skills of listening, writing, grammar, vocabulary, and speaking. Vanegas stresses that $80 \%$ of an English course at the university level should be based on reading and $20 \%$ on writing.

To plan a course where reading is embraced as the primary tool for teaching English as a foreign language, it is fundamental to consider the following:

- First, the students' population. When we know the interests of our students, the individuality and synergy present in each student, and in the group with which we work, in addition to their overall English level, we will be able to select appropriate methodologies together with the School Administration, students, and instructors.

- Second, there must be interest, motivation, and a positive attitude towards English language learning and teaching processes in both teachers and students. For the authors, these are determining factors for accomplishing language learning.

- Third, we must think about the proper selection of reading materials that will comprise much of the content of the teaching-learning program for specific courses.

By doing so, postsecondary learners can be motivated to learn English as a foreign language, their levels of confidence can increase, and chances of using their transferring skills from L1 to L2 would undoubtedly improve.

Additionally, when adult EFL/ESL learners have had no or little exposure or have not been exposed to their first written language in a daily routine either at elementary, high school, or university level, they need to be taught how the written language works and should receive individual ESL literacy instruction, in addition to oral ESL practices (Burt, Peyton, \& Adams, 2003). They also need to be given opportunities to speak their minds, to propose English curricula where reading can be the foundation for their language skills development. According to Carlino (2005), "Reading and writing are always present in developing communications in scientific conferences, professional meetings, business conferences", and academic settings. Consequently, EFL instructors should be open and flexible in providing EFL students opportunities to increase their self-confidence, to develop positive attitudes as language learners as well as to become good English readers.

When dealing with adult EFL learners at the university level who are fully literate in a language written in a Roman alphabetic script (e.g., French, German, Croatian, and Spanish as in our case), they already know how to read from left to right and recognize letter shapes and fonts. This type of learner needs instruction in the specific letterto-sound and sound-syllable correspondences of English (Burt et al., 2003, p.13). However, it is essential to consider that reading in English is not the same as reading in Spanish. Reading instruction needs to be based on training ESL/EFL students in new ways of talking and thinking about the texts (Mikulecky, 2008).

\section{English Credit Courses from the Language Department} of the Universidad de Cuenca

English courses for credits offered by the Language Department (LD) are part of the three required courses that all UC students must take as a prerequisite for graduation. Each of these courses consists of 16 weeks of classes per semester, with a workload of 6 hours per week, and 96 hours per semester. The total number of hours for the three credit courses is 288 (three mandatory levels of English Instruction), a total of 18 credits, and is administered by the LD teaching staff. The most typical methodology in these courses is a grammar oriented and commercial textbook-based one, as stated in the course syllabi. The overall goal is to use English as a means of communication in real-life situations at an intermediate level (Meyer, 2014). The main feature of this course not only emphasizes the language practice through different physical and technological resources but also the development of strategies and techniques that are the basis for continuous and autonomous learning. The general objective of this course is to achieve the A2 level of the Common European Framework Reference for Languages (CEFRL) (Trim et al., 2001) through a balanced development of the four macro language skills: reading and listening comprehension as well as written and speaking skills to become a basic language user.

\section{English credit courses in the School of Psychology}

The focus of English courses I, II, and III, at the Psychology School of the Universidad de Cuenca, consists of a sequence of beginning to intermediate levels and take into consideration students' academic, professional, personal interests and needs. The primary purpose is to provide English instruction according to the specific academic students' needs. It focuses on training students to read and understand materials in English that are relevant to their majors, developing skills of comprehension, and analyzing various general English and major-oriented reading material to comply with the requirements of the Consejo de Educación Superior (2016). Students at the end of 288 hours are supposed to acquire the A2/B1 level of the CEFRL. Students can also develop their writing, vocabulary, and grammar in context skills by using different materials in the teaching-learning process. The Eclectic methodology, consisting of a series of activities combined with different methods of teaching English as a foreign language, is mainly applied. The emphasis is on reading activities as a teaching tool for the acquisition of other language skills such as writing, understanding, analyzing texts, contextualizing grammar, pronunciation, listening, and speaking.

\section{METHOD}

\subsection{Type of study}

This is a cross-sectional study that describes research on the benefits of the use of reading to teach EFL, as well as the levels of confidence gained from reading general and academic English texts.

\subsection{Sample}

The participants in this research corresponded to two English A1/A2 levels from the CEFRL groups that took 
this class during the semester of September 2019 to February 2020 as a mandatory prerequisite for graduation. There were $19(9 \mathrm{M}, 10 \mathrm{~F})$ students in the morning group and $21(5 \mathrm{M}, 16 \mathrm{~F})$ in the afternoon. A total of $37(26 \mathrm{~F} / 11$ M) from Psychology, Law, Medicine, Philosophy, Design, and Chemistry majors was the sample. One student did not participate in the study due to his visual impairment ${ }^{2}$ and two of them quit the program (see Table $1)$.

Table 1. Participants demographics.

\begin{tabular}{lll}
\hline Variable & & Percent \\
\hline Sex & Female & 70.27 \\
& Male & 29.73 \\
\hline Field of study & Chemistry & 2.70 \\
& Arts & 2.70 \\
& Medicine & 2.70 \\
& Philosophy & 8.11 \\
& Law & 16.22 \\
& Psychology & 67.57 \\
\hline Semester enrolled & Fifth & 21.62 \\
& Seventh & 18.92 \\
& Eight & 18.92 \\
& Ninth & 8.11 \\
& Tenth & 24.32 \\
& Graduated & 8.11 \\
\hline
\end{tabular}

\subsection{Reading materials}

The reading materials, as contained in the syllabus, were discussed, and chosen by the students and the instructor whose first language (L1) is Spanish. Students chose their one thousand to one thousand five hundred-word academic/scientific topic of interest, and a raffle was made to choose 6 to be read during the semester. As part of the reading material students also used general English reading exercises from the reading platform readtheory.org ${ }^{3}$.They worked on an average of five General English readings per week.

\subsection{English instruction for reading activities}

Several teaching activities were carried out during the semester, and they had the objective of training and enabling students to improve their overall English language skills, and specifically their reading skills.

\section{Skimming}

Skimming practices served the students to find the general idea of the text. It was interesting to note the level of prior knowledge, or background information, students had. It is important to state the similarity between Spanish and English academic and scientific terminology and the numerous cognates found in the readings, which surely helped them to increase their level of comprehension.

\section{Scanning}

Scanning was another reading technique used to find keywords or ideas, answers to questions about the text, or details such as tables, graphs, titles, subtitles, text organization, words in italics or bold, and various types of keywords.

\footnotetext{
${ }^{2} \mathrm{~A}$ personal and tailored approach was developed to cover his
} needs

\section{Mining}

Tsai (2006) uses this term to indicate the in-depth analysis performed in reading texts of valuable language resources such as grammar, vocabulary, punctuation, organizing ideas, and more. Participants in this study were encouraged to carefully observe and analyze how a reading text in English is structured: titles, subtitles, new words relevant to the text, grammar structures, paragraphs, main and supporting sentences, and other structural elements. This exercise allowed students to form clear and critical ideas on how to write in English and gave them the foundations to write better through simple imitation. The use of an extensive vocabulary in reading exercises applied in and outside classes allowed students to achieve a significant increase in vocabulary, pronunciation, and grammar analysis.

\section{Reading monitoring}

Weekly tests prepared by both the instructor and students and given to students, using questionnaires with true/false statements, completion, matching, inference, multiplechoice and open questions were used during this language course. Such activities were open book to comply with the stated objective of these English courses. Additionally, students performed a three to a five-minute oral presentation about their selected readings. The instructor also provided several web sites in the course syllabi, English books, newspapers, reading tips, and so on to encourage in students the love of reading in a foreign language.

\subsection{Reading tips for an Ecuadorian university context used in the study}

Pre-reading activities

As prereading activities, students would look at the title and subtitles, graphs, pictures, tables, and more details of the chosen reading material and think about it for a moment to activate their prior knowledge on the subject. They were encouraged to form pictures in their minds, infer, and discuss with their peers about it. As oral and writing practices, they talked and wrote about their previous knowledge about the reading topic.

\section{While reading activities}

While performing the reading exercises, students underlined/highlighted the new vocabulary or the most important information they found. When reading paragraph by paragraph, they identified the different grammar structures based on the A1-A2 language skills according to the CEFRL charts. They also summarized in two to three phrases or sentences the most relevant information of each paragraph and started to write questions about the topic according to the information they read in each paragraph. Additionally, the instructor encouraged them to color the text or use pictures that can represent each paragraph. Also, students discussed the topic with their peers mostly in English. The role of the instructor was to monitor and assist students in their understanding and the writing of questions during these reading activities.

\footnotetext{
${ }^{3}$ https://readtheory.org/
} 


\section{After-reading activities}

Students formulated questions, presented a one-minute summary of the most relevant information they had about the topic they read. They worked in pairs or groups of three to write twenty questions ${ }^{4}$ about the topic. These twenty questions were distributed among them to be answered. Additionally, students shared their answers to recycle the information. As final tasks, students wrote a three-hundred-word journal and made 3-5-minute presentations about the topic.

\subsection{Procedure}

\section{Administration of reading tests (rt)}

During the second half of the semester September 2019February 2020, the first General English reading test about Chocolate $^{5}$ was given on November 11, 2019. It is a 600word long low advance reading passage with 5 comprehension and 5 vocabulary questions. The second General English reading test about Chinese New Year ${ }^{6}$, an A2 level reading test, was given on December 11, 2019. It contains 357 words and 10 questions (3 true/false, 3 completion, 3 multiple-choice, and 1 matching question). The third about Mountain Area Forecast was given on January 13,2020 . It is a 313 -word long A2 reading test with 10 multiple-choice questions. The fourth reading test about Second Language learning and changes in the brain (Osterhout et al., 2008) took place on January 20, 2020. It is a 5,140-word long academic article with 24 questions prepared by the instructor and the fifth reading test about English Songs as an Effective Asset to Improve Listening Comprehension ability; Evidence from Iranian EFL Learners Rahbar \& Khodabakhsh (2013), a 2,283-word long scientific article with 20 questions was given on February 3, 2020.

For the three general English readings tests, (rt1, rt2, and rt3) the time allotted to complete the tests was an average of 20 minutes, and an hour and thirty minutes for the two academic reading tests ( $\mathrm{rt} 4$ and rt5). Additionally, participants took a listening, reading, and grammar English pre-and post-test during the September 2019February 2020 semester.

Finally, for assessing the level of confidence in reading academic and general English texts, at the end of the semester, participants answered the Level of personal confidence in learning English attributed to reading activities questionnaire ( $\alpha .7 .28)$. It consists of five statements related to reading confidence: 1) I feel very confident when reading academic/scientific articles in English; 2) I feel very confident when reading general English material; 3) Performing reading activities in English has helped me improve my other English language skills (writing, listening, comprehension, speaking, grammar and vocabulary); 4) I think I can learn English by reading academic/scientific and general English articles mainly, and 5) Reading has increased my level of confidence when I need to search for information in English. Students responded to this questionnaire by selecting Strongly Agree, Agree, Neither Agree nor Disagree, Disagree, or Strongly Disagree. Numerical

\footnotetext{
${ }^{4}$ Four True-False statements, four multiple-choice questions, four matching questions, four completion questions, four whquestions.

${ }_{5}^{5}$ Chocolate Reading. Retrieved from

https://www.englishforeveryone.org/PDFs/Informational\%20Pa ssages\%20RC\%20-\%20Chocolate.pdf.
}

values of 5-1, to Strongly agree (SA5), Agree (A4), Neither agree nor disagree (NAD3); Disagree (D2), and Strongly disagree (SD1), respectively, were used to quantify data.

\section{FINDINGS}

The research data came from the assessment of five reading tests (Academic and General English) worth 10 points each, an online pre-and post-test on the Listening, Reading, and Grammar skills, and from an online questionnaire on confidence levels for reading in English. The statistical results of the five reading tests are shown in Figure 1. There was a significant degree of understanding (average: 7.1) which was stable. However, there was a downtrend in the understanding of rt3. Not all the participants took rt1, rt2, and rt4 because they were absent on the testing days.

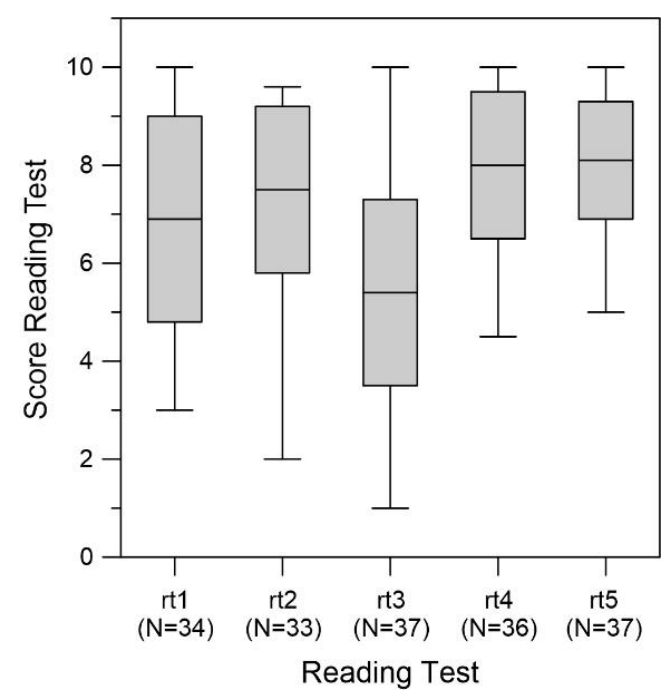

Figure 1. Statistical results of the five Reading Tests (scores: minimum, $\overline{\mathrm{X}}-\mathrm{SD}, \overline{\mathrm{X}}, \overline{\mathrm{X}}+\mathrm{SD}$, maximum).

Table 2 shows the statistically significant difference between the results on the Academic Reading Tests (ART) versus the General Reading Test (GRT). It is worth noting that there was a better understanding of Academic English material (7.99) in comparison to General English (6.54).

Table 2. Differences between ART versus GRT.

\begin{tabular}{ccccc}
\hline & ART & GRT & $\mathrm{t}$ & $\mathrm{p}$ \\
\cline { 2 - 5 } Average & 7.99 & 6.54 & -8.44 & $0.001^{*}$ \\
\hline Note: $* \mathrm{p}<0.001$ & & & &
\end{tabular}

Figure 2 depicts the percentages of an online (English Store $^{7}$ ) pretest $(55.22 \%$ ) and a posttest $(65.77 \%)$ on reading and listening as well as a pretest (45.51) and a

\footnotetext{
${ }^{6}$ Chinese New Year Reading. Retrieved from https://www.testenglish.com/reading/a2/chinese-new-year/

${ }^{7}$ Retrieved from

https://englishteststore.net/index.php?option=com_content\&vie $\mathrm{w}=$ article \&id=11400\&Itemid $=123$
} 
posttest (60.22) on grammar skills according to the CEFRL (Trim et al., 2001).

Table 3 shows the results of the Online Pretest (OT-Pre) versus the Online Posttest (OT-Post) which assessed Listening and Reading skills and between Grammar Pretest (GRPre) and Grammar Post-test (GRPost). It is worth noting that there was a statistically significant difference in the grammar pre-and post-test.

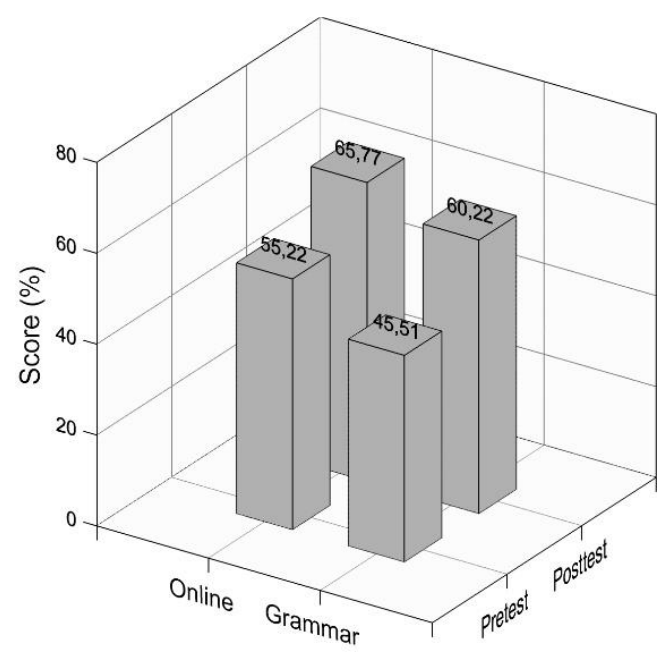

Figure 2. The score difference between Online Reading and Listening and Grammar Pre- and Post-tests.

Table 3. Difference between Pre and Post-tests.

\begin{tabular}{|c|c|c|c|c|}
\hline & OT-Pre & OT-Post & GRPre & GRPost \\
\hline Average & 54.16 & 64.29 & 45.51 & 59.88 \\
\hline $\mathrm{t}$ & \multicolumn{2}{|c|}{-2.96} & \multicolumn{2}{|c|}{-6.73} \\
\hline $\mathrm{p}$ & \multicolumn{2}{|c|}{0.005} & \multicolumn{2}{|c|}{$0.001 *$} \\
\hline
\end{tabular}

Note: ${ }^{*} \mathrm{p}<0.001$

Figure 3 shows the results of the Level of personal confidence in learning English attributed to the reading activities questionnaire.

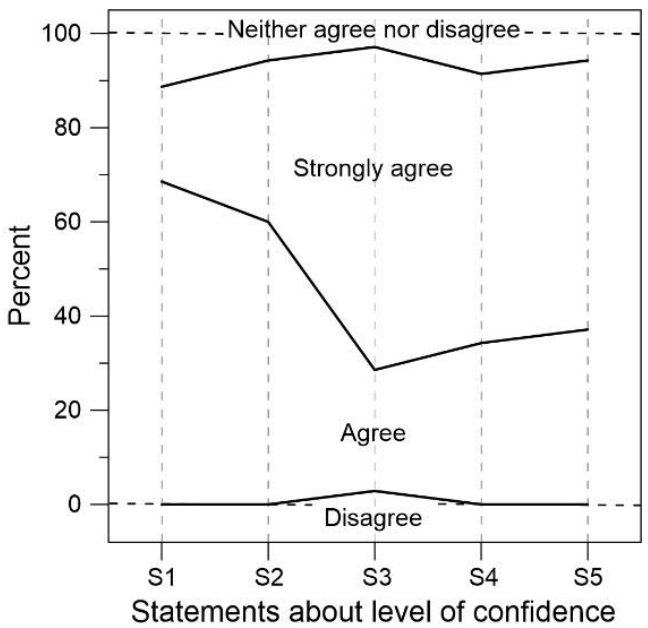

Figure 3. Percentage of agreement and disagreement on the levels of confidence when reading in English.

Thirty-five participants responded to the statements (S) about the levels of confidence when reading in English
(S1, S2, S3, S4, and S5) in a positive way. Only $2.86 \%$ disagreed on $\mathrm{S} 3$, but the rest of the responses gave positive confirmations on their levels of confidence when reading either academic or general English.

\section{DISCUSSION}

Results indicated an overall robust and significant improvement in understanding reading texts related to general and academic English. We also saw a significant difference between the pre-and post-test online and grammar tests. Additionally, we found that confidence levels in reading both for Academic and General English material were high. It is, therefore, possible to include reading as an educational tool in regular courses as it provides the possibility of further improvements in English teaching and learning. Interestingly, the use of reading as the leading English didactical tool is a different methodological experience. It motivates students to learn and understand reading material related to university courses and increases their ability to understand more technical and general vocabulary. This teaching approach might be conducive for the improvement of writing, vocabulary development, listening, and oral skills and can expand students' knowledge in their majors. Pluck (2013) in her findings stated that including the reading of academic and scientific articles in teaching English can be more challenging for university students. However, the benefits of this type of approach are noteworthy and feasible to carry out. We contend that challenging university students as well as language instructors when dealing with teaching methodologies must be the core of any English Program offered at the university level. The results also show that when giving the students the possibility of reading what they are interested in or what they are studying in their majors, chances of success in understanding English material and confidence levels in reading increase.

Feyen (2014), Ramírez (2013), Vanegas, in Meyer's report (2014), and Krashen (1985) recommend including the practices of intensive and extensive reading as well as writing practices in our English courses. Reading and writing are the two most crucial core language skills used by the English language program offered at UC's Psychology School. Reading is taken as the foundation for the development of the other language skills as mentioned by Richard \& Smith (2002) who argue that developing the reading habits, encourages the knowledge of grammar structures and vocabulary, and nurtures the love of reading. Participants reported that writing summaries, making oral presentations, and discussing and making analyses of what they read during the semester gave them the possibility of developing their overall English language skills. The listening component of the program was achieved through listening to the instructors, peers, video presentations, TED Talks, and YouTube songs.

To sum up, reading generated the possibility of offering a variety of activities that allowed students to practice the four primary language skills. Additionally, we noticed sudden changes in students' motivation, levels of selfconfidence, engagement, and changes in their attitudes toward learning English.

However, looking at the results shows us that some participants indicated that the readings assigned for this 
English course were very extensive and that there was a lot of new and challenging vocabulary to understand. The study done by Pluck (2013) showed similar results. This approach presented new challenges and demands, but there were obstacles to overcome to gain the significant benefits that it offered to this type of student population.

\section{CONCLUSIONS AND IMPLICATIONS}

Reading should occupy an essential and significant place in the English teaching and learning process and be incorporated more frequently in regular language courses at university levels. It is recommended not to underestimate students' capabilities and linguistic transfer skills that add to this type of educational strategy, where the main emphasis is the understanding of academic and scientific material related to their majors. Similarly, language instructors should be more aware that some students nowadays enter university much better prepared in English language. They should also realize that English reading comprehension is one of the most evaluated skills in almost all the entrance examinations in most foreign universities and graduate programs at the national or international level. Therefore, our students need to take more advanced, demanding, and challenging English courses that genuinely prepare and enable them to take international standardized tests such as the TOEFL, GRE, CEFRL, and so on for admission to foreign universities or master or doctoral programs offered worldwide. Using reading to teach EFL might catapult students from being ready for more significant and more rewarding challenges.

Nevertheless, an EFL instructor must be a role model. A language teacher, whether at a university, high or elementary school level, who does not read, cannot be a good example and will not be able to motivate students to read. Therefore, good reading teaching habits must be mandatory as part of any EFL training to increase the level of students' motivation to read.

There are numerous EFL methodologies mentioned by research about teaching English as a foreign language that responds to different approaches, paradigms, interests, contexts, and realities (Menezes, 2013). It is evident to Ecuadorian English instructors that not all students who are pursuing university majors intend to study their master or doctoral programs in English-speaking countries or become pure researchers. On the contrary, the main concern and intention of most of them are passing the three mandatory English language courses, currently to reach the B1 level, to comply with one of their undergraduate requirements for graduation. Therefore, our work as university professors should be to make these groups of students realize and consider the enormous possibilities that knowing English can offer them. If students do not have the intention to pursue graduate studies within or outside the country where English is required, they should at least be aware of and ponder upon the enormous benefits that learning another language represents, not only in academia but also in their professional and personal lives. Consequently, we think that reading can be used as an educational tool and must be included in the daily practice of teaching and learning foreign languages at university levels, for it can serve to better students' English learning skills.
The authors argue that reading can enhance the rest of language skills, and the motivation to learn this foreign language at the university level because our student populations already have an acceptable level of literacy in L1 which affects the literacy skills that learners can transfer from L1 to L2 reading (Grabe \& Stoller, 2002).

Finally, we conclude by inviting language instructors to consider the possibility of incorporating reading as a useful didactical tool for language instruction and conducting further research on this critical issue with bigger populations and in different universities, schools, and contexts.

\section{ACKNOWLEDGEMENTS}

The authors express their gratitude to the School of Psychology and the Language Department of the Universidad de Cuenca for promoting and supporting research projects in the EFL area. Our thanks also go to the university students who participated in this study.

\section{REFERENCES}

Aebersold, J., \& Field, M. (1997). From reader to reading teacher: Issues and strategies for second language classrooms. Cambridge: Cambridge University Press.

Beglar, D., Hunt, A., \& Kite, Y. (2012). The effect of pleasure reading on Japanese university EFL learners' reading rates. Language Learning, 62(3), 665-703. https://doi.org/10.1111/j.1467-9922.2011.00651.x

Bernal, M. \& Feyen, J. (2017). Preliminary response from the Faculty of Psychology students of the University of Cuenca to the modified EFL teaching approach. Maskana, 8(1), 61-69.

Brophy, J. (1986). On motivating students. Occasional Paper No. 101. East Lansing, Michigan, US: Institute for Research on Teaching, Michigan State University, October 1986. Retrieved from:

http://files.eric.ed.gov/fulltext/ED276724.pdf

Burt, M. Peyton, J. K., \& Adams, R. (2003). Reading and adult English language learners: A review of the research. Washington DC.: Center for Applied Linguistics. Retrieved from:

http://files.eric.ed.gov/fulltext/ED505537.pdf

Carlino, P. (2005). Enseñar no solo exponiendo. Enseñar a exponer en la Universidad. Educación, Lenguaje y Sociedad, III(3), 207-229.

Consejo de Educación Superior (2016). Codificado del Régimen Académico del 4 de mayo del 2016, CES, artículo 31, p.21.

Chang, A. (2012). Improving reading rate activities for EFL students: Timed reading and repeated oral reading, 24(1), 56-83.

Chang, A., \& Millet, S. (2017). Narrow reading: Effects on EFL learners' reading speed, comprehension, and perceptions. Reading in a Foreign Language, 29(1), 1-19. 
Chen, H., \& Yang, Y. (2015). EFL students' perceptions of top-down and bottom-up reading strategies and reading comprehension. Retrieved from http://ir.lib.au.edu.tw/bitstream/987654321/4661/1/201 50320-135-151.pdf

Day, R. (2015). Extending extensive reading. Reading in a Foreign Language, 27(2), 294- 301.

Eskey, D., \& Grabe, W. (1988). Interactive models for second language reading: Perspectives on instruction. In: Carrell, P., Devine, J., \& Eskey, D. (Eds.), Interactive approaches to second language reading (pp. 223-238). New York, NY: Cambridge University Press.

Feyen, J. (2014). How to bring research into the classroom. From: Universidad de Docencia a Universidad de Docencia con Investigación. PowerPoint Presentation, Slide 11.

Grabe, W., \& Stoller, F. L. (2001). Reading for academic purposes: Guidelines for the ESL/EFL teacher. In: Celce-Murcia, M. (Ed.), Teaching English as a Second or Foreign Language (3rd ed., pp. 187-204). USA: Heinle \& Heinle.

Grabe, W., \& Stoller, F.L. (2002). Teaching and researching reading. Harlow, England: Pearson Education.

Khaki, N. (2014). Improving reading comprehension in a foreign language. The Reading Matrix, 14(2), 186-200.

Krashen, S. (1985). Insights and Inquires. Hayward, CA: Alemany Press.

Krashen, S. (2004). Free voluntary reading: New Research, Applications, and Controversies. RELC conference, Singapore, April 2004, 1-9.

Krashen, S. D. (1996) The case for narrow listening. System, 24, 97-100.

Kintsch, W. (2005). An overview of top-down and bottom-up effects in comprehension: The CI perspective. Discourse Processes, 39(2-3), 125-128.

Loh, J. K. K. (2009). Teacher modeling: Its impact on an extensive reading program. Reading in a Foreign Language, 21(2), 93-118.

McQuillan, J. (2016). What can readers read after graded readers? Reading in a Foreign Language, 28(1), 63-78.

Menezes, V. (2013). Second language acquisition: Reconciling theories. The graduate program in linguistic studies, Federal University of Minas Gerais, Belo Horizonte, Brazil. Open Journal of Applied Sciences, 3, 404-412.

Meyer, L. (2014). Progress Report of the Evaluation of the English Language Program Universidad de Cuenca, Ecuador. Department of Language, Literacy \& Sociocultural Studies, and Latin American Programs in Education (LAPE). College of Education, University of New Mexico, Albuquerque, NM, USA.

Mikulecky, B. (2008). Teaching reading in a second language. Pearson Education, Inc. Reading Monograph, 1-6. Retrieved from http://longmanhomeusa.com/blog/teachingreading-ina-second-language/

Miller, S. D. (2003). How high-and low-challenge tasks affect motivation and learning: Implications for struggling learners. Reading \& Writing Quarterly, 19(1), 39-57. https://doi.org/10.1080/10573560308209
Mounts, E., \& Smirnova, L. (2011). A task-based approach to teaching reading. INTED2011 Proceedings, pp. 4046-4050. Retrieved from: https://library.iated.org/view/MOUNTS2011ATA

O’Malley, J., \& Chamot, A. (1990). Learning Strategies in Second Language Acquisition. Cambridge University Press. Retrieved from: http://catdir.loc.gov/catdir/ samples/cam031/89009770.pdf

Osterhout, L., Poliakov, A., Inoue, K., McLaughlin, J., Valentine, G., Pitkanen, I., Frenck-Mestre, C., \& Hirschensohn, J. (2008). Second-language learning and changes in the brain. Journal of Neurolinguistics, 21(6), 509-521. https://doi.org/10.1016/j.jneuroling. 2008.01.001

Paul, R., \& Elder, L. (2008). How to read a paragraph: The art of close reading. Foundation for Critical Thinking Press. Tomales, California, Retrieved from: https://www.robeson.k12.nc.us/site/handlers/filedownl oad.ash $x$ ?moduleinstanceid $=40522 \&$ dataid $=55321 \&$ Fil eName $=$ How $\% 20$ to $\% 20$ Read $\% 20 a \% 20$ Paragraph.pdf

Pluck, G. (2013). Teaching Psychology through English. Incidental improvement in academic reading comprehension. Journal of Educational Services in Psychology, LXV(1/2013), 38-42

Rahbar, S., \& Khodabakhsh, S. (2013). English songs as an effective asset to improve listening comprehension ability; Evidence from Iranian EFL learners. International Journal of Applied Linguistics \& English Literature, 2(6), 63-66. https://doi.org/0.7575/ aiac.ijalel.v.2n.6p.63

Ramírez, R. (2013). Boletín de Prensa No. 128, Julio 23, 2013. Quito, Ecuador: Secretaria Nacional de Education, Ciencia, Tecnología e Inovación (SENESCYT).

Richard, J. C. \& Schmidt, R. (Eds.). (2002). Longman dictionary of language teaching and applied linguistics. (3rd ed.) London: Longman, 193-194.

Schmitt, N., \& Carter, R. (2000). The lexical advantages of narrow reading for second language learners. TESOL Journal, 9(1), 4-9.

Taguchi, E., Takayasu-Maass, M., \& Gorsuch, G. (2004) Developing reading fluency in EFL: How assisted repeated reading and extensive reading affect fluency development. Reading in a Foreign Language, 16(2), 70-96.

Toland, S., \& Fuisting, B. (2017). Read, create, and speed, mingle! TexTESOL IV - Spring, 33(1), 15-19.

Torrie, H. (2017). Preparing students for academic writing by using stem topics and tasks. TexTESOL IVSpring, 33(1), 22-25.

Trim, J., Coste, D., North, B., \& Sheils, J. (2001). Common European Framework of Reference for Languages (CEFRL). Council of Europe in English (Cambridge), and in French (Didier).

Tsai, J. (2006). Connecting reading and writing in college EFL courses. The Internet TESL Journal, XII(12). Retrieved from: http://iteslj.org/Articles/Tsai. ReadingWritingConnection.html

Yan, T. (2017). Close reading: The historical trends and application to English learners. TexTESOL IV - Spring, 33(1), 38-41. 